\title{
EVALUATION OF PENICILLIN THERAPY IN PATIENTS WITH LEPTOSPIROSIS AND ACUTE RENAL FAILURE
}

Elizabeth De Francesco DAHER(1,2) \& Charlys Barbosa NOGUEIRA(1)

\begin{abstract}
SUMMARY
The effectiveness of specific antibiotic treatment in severe leptospirosis is still under debate. As part of a prospective study designed to evaluate renal function recovery after leptospirosis acute renal failure (ARF) (ARF was defined as $\mathrm{P}_{\text {cr }} \geq 1.5 \mathrm{mg} / \mathrm{dL}$ ), the clinical evolutions of 16 treated patients $(\mathrm{T})$ were compared to those of 18 untreated patients (nT). Treatment or non-treatment was the option of each patient's attending infectologist. The penicillin treatment was always with 6 million IU/day for 8 days. No difference was found between the two groups in terms of age, gender, number of days from onset of symptoms to hospital admission, or results of laboratory tests performed upon admission and during hospitalization, but proteinuria was higher in the treated group. There were no significant difference in the other parameters employed to evaluate patients' clinical evolution as: length of hospital stay, days of fever, days to normalization of renal function, days to total bilirubins normalized or reached 1/3 of maximum value and days to normalization of platelet counts. Dialytic treatment indication and mortality were similar between group T and nT. In conclusion, penicillin therapy did not provide better clinical outcome in patients with leptospirosis and ARF.
\end{abstract}

KEYWORDS: Acute renal failure; Leptospirosis and penicillin.

\section{INTRODUCTION}

Leptospirosis is a zoonosis of worldwide distribution that is characterized by various clinical manifestations, in which man plays an accidental role in the epidemiologic chain. Although the majority of cases are self-limited, the most severe manifestation, known as Weil's syndrome, occurs in approximately $10 \%$ of cases and is typified by jaundice, renal dysfunction, hemorrhagic manifestations and pulmonary involvement ${ }^{8,19,23}$. Leptospirosis has caused concern among epidemiologists and clinicians alike due to the difficulty in its eradication, caused by the complex social, epidemiologic and economic aspects with which it is connected, as well as the high mortality rate which it presents.

The efficacy of antibiotic therapy in the treatment of human leptospirosis has been debated for over 50 years. Although there is evidence that various antimicrobial agents, such as penicillin, tetracyclines, ampicillins, streptomycins, cephalothin, and others are active in vitro and in experimental infections, the indications for antibiotic therapy in leptospirosis remain controversial even to this day ${ }^{1,3}$.

Various studies ${ }^{4,10,12,16-18}$ have suggested that the use of antibiotic therapy could be beneficial to patients, curtailing the duration of the disease and reducing complications. Administration of the drugs seems to be effective when initiated up to the fourth day after onset of symptoms.
Studies show that the use of doxycycline in the anicteric form of leptospirosis was effective in reducing the duration of the disease, easing symptoms such as myalgia, headache, asthenia and fever ${ }^{14}$. Doxycycline is effective when employed in prophylactic fashion against leptospirosis ${ }^{22}$. The benefits of the use of intravenous penicillin in the severe form of leptospirosis (Weil's syndrome) have been demonstrated in controlled study even when administered late in the course of the disease ${ }^{25}$. However, other reports did not witness benefits in the use of penicillin in the clinical evolution of patients with the severe form of leptospirosis ${ }^{9,11}$. Therefore, efficacy of antibiotic therapy in the late phase of the severe form of the disease remains in discussion.

With the purpose of verifying whether treatment with penicillin has influence on the clinical evolution of patients with leptospirosis and acute renal failure (ARF), an analysis was developed as part of a prospective study of renal function in these patients, in order to determine whether or not penicillin modifies disease evolution.

\section{PATIENTS AND METHODS}

During the period of May 1996 to June 1998, 43 patients with clinical suspicion of leptospirosis were hospitalized in the Nephrology Service of the Walter Cantídio University Hospital in the Faculty of Medicine of the Federal University of Ceará. Eight patients were excluded at the

(1) Hospital Universitário Walter Cantídio, Departamento de Medicina Clínica, Faculdade de Medicina, Universidade Federal do Ceará, Fortaleza, CE, Brasil.

(2) Hospital das Clínicas, Serviço/Disciplina de Nefrologia, Faculdade de Medicina, Universidade de São Paulo, São Paulo, SP, Brasil.

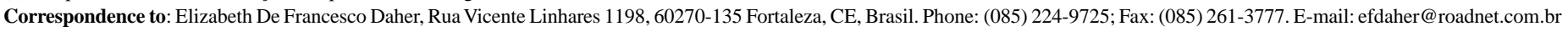


time of admission: two patients who were over 60 years of age, one patient who had renal lithiasis, another who did not have the diagnosis of leptospirosis confirmed by serology, and 4 patients who died within the first forty-eight hours of admission, on penicillin therapy, with massive haemoptysis and acute respiratory distress syndrome. In this manner, 35 patients were studied prospectively, 30 of which were males and 5 females, with ages within the range of 18 to 55 years (average $35 \pm 10$ years) and with epidemiologic data and clinical and laboratory diagnoses of leptospirosis. All patients were on ARF, defined as plasma creatinine (Pcr) higher than $1.5 \mathrm{mg} / \mathrm{dl}$ and jaundice on admission.

An analysis was conducted as part of a prospective study of renal function. In these cases, the severity of the disease was based on WATT et $a l .{ }^{25}$ report. The illness was considered severe if acute renal failure and jaundice were presented on admission. The Acute Physiologic and Chronic Health Evaluation (APACHE II) score and the number of Organ System Failure were not recorded in this study.

Hemorrhagic phenomena as gastrointestinal hemorrhage, hemoptysis and epistaxis were recorded at admission and during hospitalization and respiratory failure was defined as $\mathrm{PaO}_{2}$ less than $90 \mathrm{mmHg}$.

The presumptive diagnosis of leptospirosis was made by the clinical state and epidemiologic antecedents and was confirmed by the presence of IgM class-specific antibodies in titers $\geq 1: 400$ in blood samples collected in the $15^{\text {th }}$ day after the onset of symptoms ${ }^{2}$.

The patients were assigned as group $\mathrm{T}(\mathrm{n}=16)$, treated with penicillin, and group nT (n=19), untreated. In the São José Hospital of Infectious Diseases, where screening and transfers cases of jaundice and ARF leptospirosis to the Walter Cantídio University Hospital occurred, there are two groups of infectologists: one does not use specific antibiotic therapy, and the other does. Conduct is maintained independent of clinical state. Therefore, when the patient was already under the use of specific antibiotic therapy, this was maintained. Specific antibiotic therapy consisted of crystalline penicillin in doses of 6 million IU/day intravenously during eight days.

Plasma concentrations of urea, creatinine $\left(\mathrm{P}_{\mathrm{cr}}\right)$, potassium $\left(\mathrm{P}_{\mathrm{K}}\right)$, sodium $\left(\mathrm{P}_{\mathrm{Na}}\right)$, total bilirrubin $(\mathrm{TB})$, aspartate and alanine amino transferase (AST and ALT), lactic dehydrogenase (LDH), creatine kinase (CK), serum albumin, arterial gasometry, complete hemogram, peripheral platelet counts and 24 hour proteinuria $\left(\mathrm{U}_{\text {prot }}\right)$, were dosed on admission and three times a week during hospitalization. Data obtained on admission and maximum laboratory values of urea, $\mathrm{P}_{\mathrm{cr}}, \mathrm{CK}, \mathrm{LDH}, \mathrm{P}_{\mathrm{K}}, \mathrm{AST}, \mathrm{ALT}$, $\mathrm{TB}$, and $\mathrm{U}_{\text {prot }}$ during hospital stay were analyzed, as also were the minimum blood values of $\mathrm{P}_{\mathrm{K}}, \mathrm{P}_{\mathrm{NA}}$, serum albumin, peripheral platelet counts, $\mathrm{pH}, \mathrm{PaO}_{2}$ and bicarbonate.

Other parameters employed to evaluate patients' clinical evolution were: time between the onset of symptoms and hospital admission $(\Delta \mathrm{S})$, time of hospitalization $(\Delta \mathrm{H})$, number of days the patient presented with temperatures above $37.5{ }^{\circ} \mathrm{C}(\Delta \mathrm{F})$, number of days of patient oliguria $(\Delta \mathrm{OL})$, number of days the patient presented with $\mathrm{P}_{\mathrm{cr}} \geq 1.5 \mathrm{mg} / \mathrm{dL}\left(\Delta \mathrm{P}_{\mathrm{cr}}\right)$, number of days required for the minimum observed platelet count to reach the normal value of $150,000 / \mathrm{mm}^{3}$ ( $\Delta$ Plat) and number of days required for the maximum observed total bilirubin value to fall to a value equal to one third of its maximum value or the value of $0.8 \mathrm{mg} / \mathrm{dL}(\Delta \mathrm{TB})$.
Oliguria was defined as urinary volume below $600 \mathrm{~mL} /$ day after hydration. When the patient remained oliguric even after effective hydration, furosemide was used. The diuretic was sustained for a maximum of 48 hours for those patients in whom oliguria was not reversed.

Hydration with crystalloids and potassium replacement were administered according to the needs of each patient.

Dialysis was indicated in those patients that remained oliguric even after effective hydration, in those cases where uremia was associated with hemorrhagic phenomena or severe respiratory failure. The type of dialysis indicated was, in the majority of cases, intermittent peritoneal dialysis (IPD). In case of extreme hypercatabolism where the removal of urea was inadequately performed by IPD, classic hemodialysis or continuous slow hemodialysis was indicated in hemodynamically unstable patients.

The study protocol was approved by the Ethical Committee of the Walter Cantídio University Hospital and by the Ethical Committee for the Analysis of Research Projects of the Hospital of Clinics of the University of São Paulo. All patients gave informed consent.

For the statistical analysis of the results, the Student $t$ test was used in order to analyze variations of the $\mathrm{T}$ group compared to the $\mathrm{nT}$ group. The Fisher test was used to verify the existence of a relationship between two variables described in the form of contingency tables. The results were expressed as mean $\pm \mathrm{SD}$ and were considered significant when $\mathrm{p}<0.05$.

\section{RESULTS}

There was no statistically significant difference between $\mathrm{T}$ and $\mathrm{nT}$ group in terms of age ( $37 \pm 10$ and $32 \pm 9$ years) and gender ( 81 and $89 \%$ were male), respectively. Laboratory data at the time of admission are presented in Table 1.

Table 1

Admission laboratory data of treated and untreated groups

\begin{tabular}{lccc}
\hline & $\begin{array}{c}\text { Group T } \\
(\mathrm{n}=16)\end{array}$ & $\begin{array}{c}\text { Group nT } \\
(\mathrm{n}=19)\end{array}$ & $\mathrm{p}$ \\
\hline $\mathrm{P}_{\mathrm{cr}}(\mathrm{mg} / \mathrm{dL})$ & $4.8 \pm 2.5$ & $5.7 \pm 2.7$ & 0.28 \\
Urea $(\mathrm{mg} / \mathrm{dL})$ & $154 \pm 88$ & $173 \pm 91$ & 0.53 \\
$\mathrm{Hb}(\mathrm{g} / \mathrm{L})$ & $10.7 \pm 1.6$ & $10.8 \pm 1.5$ & 0.73 \\
WBC $\left(\mathrm{x} 10^{3} / \mathrm{mm}^{3}\right)$ & $13 \pm 6$ & $12 \pm 4$ & 0.73 \\
Platelets $\left(\mathrm{x} 10^{3} / \mathrm{mm}^{3}\right)$ & $71 \pm 46$ & $66 \pm 48$ & 0.76 \\
TB $(\mathrm{m} / \mathrm{dL})$ & $21 \pm 7$ & $20 \pm 5$ & 0.44 \\
AST $(\mathrm{IU} / \mathrm{mL})$ & $129 \pm 107$ & $106 \pm 62$ & 0.45 \\
ALT $(\mathrm{IU} / \mathrm{mL})$ & $75 \pm 44$ & $74 \pm 48$ & 0.98 \\
\hline
\end{tabular}

$\mathrm{P}_{\mathrm{cc}}$ - plasma creatinine, $\mathrm{Hb}$ - hemoglobin, WBC - leucocytes, TB - total bilirubin, AST - aspartate amino transferase and ALT - alanine amino transferase. 
The minimum and maximum laboratory values during hospital stay of both treated and untreated patients were similar, as can be seen in Tables 2 and 3, with the exception of proteinuria. In the treated group, during the acute phase of disease, proteinuria was significantly $(\mathrm{p}=0.03)$ higher $(840 \pm 610 \mathrm{mg} / \mathrm{dL})$ than that of the $\mathrm{nT}$ group $(454 \pm 246 \mathrm{mg} / \mathrm{dL})$ (Figure 1).

The clinical recovery of patients of group $\mathrm{T}$ and of group nT occurred in similar fashion, as can be seen in Table 4 . Only one patient died from group $\mathrm{T}$ during the twelfth day of hospitalization. $\Delta \mathrm{S}$ was $7.1 \pm 2.5$ days in group $\mathrm{T}$ not different $(\mathrm{p}=0.66)$ from group $\mathrm{nT}, 7.4 \pm 1.7$ days and $\Delta \mathrm{H}$ was the same $(p=0.81)$ for groups $\mathrm{T}$ and $\mathrm{nT}, 12 \pm 6$ and $11 \pm 5$ days, respectively. During hospital stay, patients in the $\mathrm{T}$ group were feverish during $3 \pm 4$ days, not different $(\mathrm{p}=0.64)$ from those in the nT group remained so for $2 \pm 3$ days. It was observed that only one patient from group $\mathrm{T}$ and one from group $\mathrm{nT}$ presented with fever for more than 20 days. The patient that died presented with fever during 4 days. $\Delta \mathrm{P}_{\mathrm{cr}}$ was $10 \pm 6$ days in group $\mathrm{T}$ and $9 \pm 6$ days in group $\mathrm{nT}$, therefore displaying no significant difference $(\mathrm{p}=0.83)$. The patient that died remained with $\mathrm{P}_{\mathrm{cr}}$ constantly elevated: $5.1 \mathrm{mg} / \mathrm{dL}$ on day of death. $\Delta \mathrm{TB}$ was $8 \pm 3$ days for both groups. The patient that died still presented with TB of $32 \mathrm{mg} / \mathrm{dL}$ on the day of death. $\Delta$ Plat value was $5 \pm 2$ in group $T$, similar $(\mathrm{p}=0.61)$ to the $4 \pm 2$ days for group $n T$. The patient that died did not present normalization of platelet count. The $\Delta \mathrm{H}, \Delta \mathrm{F}, \Delta \mathrm{P}_{\mathrm{cr}}, \Delta \mathrm{TB}$ and $\Delta \mathrm{Plat}$ were not shortened by penicillin therapy.

Episodes of bleeding as gastrointestinal hemorrhage, hemoptysis and epistaxis were observed in $44 \%$ of group $\mathrm{T}$ and $66 \%$ of $\mathrm{nT},(\mathrm{p}=0.48)$. $\mathrm{X}$-ray evidence of pneumonitis was recorded in 12 cases and $\mathrm{PaO}_{2}$ less than $90 \mathrm{mmHg}$ was present in $38 \%$ of group $\mathrm{T}$ and $37 \%$ of $\mathrm{nT},(\mathrm{p}=0.99)$. The patient, from group $\mathrm{T}$, who died had massive hemoptysis and acute respiratory distress syndrome.

The fluid balance was positive in $13(81 \%)$ patients in group $\mathrm{T}$ and in $15(79 \%)$ of group $\mathrm{nT}$, therefore displaying no statistically significant difference $(\mathrm{p}=0.60)$ between the two groups. Only three patients $(19 \%)$ of group $\mathrm{T}$ and one $(5 \%)$ of group nT remained oliguric after hydration and furosemide use; this difference also was not statistically significant $(\mathrm{p}=0.31)$ (Table 5). $\Delta \mathrm{OL}$ was $8.3 \pm 4.1$ days. Three of the oliguric patients reversed oliguria on the third, ninth and thirteenth day of hospitalization; and one patient, from group $\mathrm{T}$, remained oliguric until time of death.

There was no significant difference $(\mathrm{p}=0.57)$ between the two groups with respect to dialytic treatment. Eight $(50 \%)$ patients of group $\mathrm{T}$ and $10(52 \%)$ of group $\mathrm{nT}$ required dialysis: 17 patients received intermittent peritoneal dialysis and only one patient from group $\mathrm{T}$ received classic hemodialysis. The patients that received dialysis were submitted to, on average in the $\mathrm{T}$ group, 2.0 \pm 3.0 dialysis sessions, which was not significantly different $(\mathrm{p}=0.52)$ from those of group $\mathrm{nT}, 1.4 \pm 1.7$ sessions (Table 5).

Jarisch-Herxheimer's reaction was not seen in those patients treated with penicillin.

\section{DISCUSSION}

Leptospirosis is considered a public health problem in developing countries. In Brazil, the disease occurs in endemic fashion, however,
Table 2

Minimum laboratory data at hospitalization of treated and untreated groups

\begin{tabular}{lccc}
\hline & $\begin{array}{c}\text { Group T } \\
(\mathrm{n}=16)\end{array}$ & $\begin{array}{c}\text { Group nT } \\
(\mathrm{n}=19)\end{array}$ & $\mathrm{p}$ \\
\hline $\mathrm{P}_{\mathrm{Na}}(\mathrm{mEq} / \mathrm{L})$ & $130 \pm 5$ & $130 \pm 6$ & 0.77 \\
$\mathrm{P}_{\mathrm{K}}(\mathrm{mEq} / \mathrm{L})$ & $3.3 \pm 0.5$ & $3.2 \pm 0.6$ & 0.72 \\
${\mathrm{Platelets}\left(\mathrm{x} 10^{3} / \mathrm{mm}^{3}\right)}$ & $54 \pm 34$ & $62 \pm 48$ & 0.58 \\
$\mathrm{PH}$ & $7.40 \pm 0.01$ & $7.35 \pm 0.06$ & 0.23 \\
$\mathrm{HCO}_{3} \cdot(\mathrm{mEq} / \mathrm{L})$ & $20 \pm 4$ & $20 \pm 5$ & 0.84 \\
$\mathrm{PaO}_{2}(\mathrm{mmHg})$ & $94 \pm 19$ & $96 \pm 14$ & 0.58 \\
$\mathrm{Albumin}(\mathrm{g} / \mathrm{dL})$ & $2.7 \pm 0.5$ & $2.9 \pm 0.4$ & 0.43 \\
\hline
\end{tabular}

$\mathrm{P}_{\mathrm{Na}}$ - plasma sodium and $\mathrm{P}_{\mathrm{K}}$ - plasma potassium.

Table 3

Maximum laboratory data at hospitalization of treated and untreated groups

\begin{tabular}{lccc}
\hline & $\begin{array}{c}\text { Group T } \\
(\mathrm{n}=16)\end{array}$ & $\begin{array}{c}\text { Group nT } \\
(\mathrm{n}=19)\end{array}$ & $\mathrm{p}$ \\
\hline Plasma urea $(\mathrm{mg} / \mathrm{dL})$ & $180 \pm 111$ & $187 \pm 95$ & 0.83 \\
$\mathrm{P}_{\text {cr }}(\mathrm{mg} / \mathrm{dL})$ & $5.3 \pm 2.7$ & $6.1 \pm 2.7$ & 0.36 \\
$\mathrm{P}_{\mathrm{K}}(\mathrm{mEq} / \mathrm{L})$ & $4.8 \pm 1.0$ & $4.3 \pm 0.7$ & 0.16 \\
$\mathrm{CK}(\mathrm{IU} / \mathrm{L})$ & $1491 \pm 4869$ & $106 \pm 782$ & 0.43 \\
$\mathrm{LDH}(\mathrm{IU} / \mathrm{L})$ & $697 \pm 454$ & $728 \pm 318$ & 0.82 \\
$\mathrm{~TB}(\mathrm{mg} / \mathrm{dL})$ & $22 \pm 7$ & $21 \pm 8$ & 0.53 \\
$\mathrm{U}_{\text {prot }}(\mathrm{mg} / \mathrm{day})$ & $840 \pm 610^{*}$ & $454 \pm 246$ & 0.03 \\
\hline
\end{tabular}

*Significant, $\mathrm{p}<0.05$ vs group $\mathrm{nT} ; \mathrm{P}_{\mathrm{cr}}$ - plasma creatinine, $\mathrm{P}_{\mathrm{K}}$ - plasma potassium, $\mathrm{CK}$ - creatine kinase, TB - total bilirrubin and $\mathrm{U}_{\text {prot }}$ - urinary protein excretion.

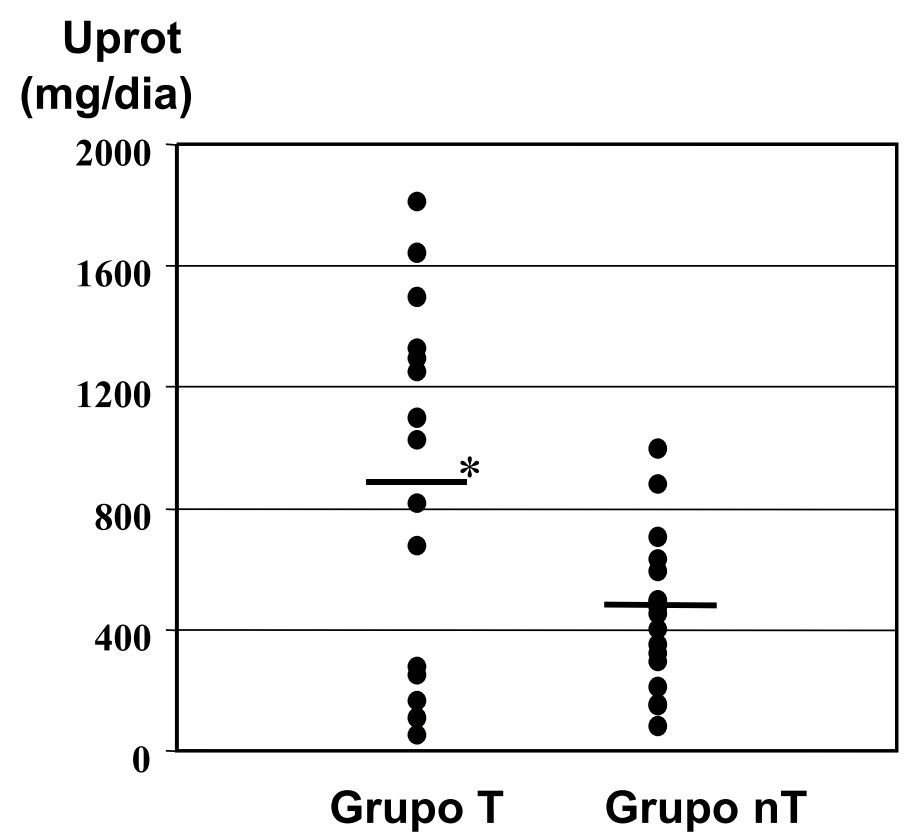

Fig. 1 - Urinary excretion of proteins during the acute phase of disease in treated and untreated patientis. ${ }^{*} \mathrm{p}<0.05$ vs group $\mathrm{nT}$. 
Table 4

Parameters to evaluate clinical evolution of treated and untreated groups

\begin{tabular}{lccc}
\hline & $\begin{array}{c}\text { Group T } \\
(\mathrm{n}=16)\end{array}$ & $\begin{array}{c}\text { Group nT } \\
(\mathrm{n}=19)\end{array}$ & $\mathrm{p}$ \\
\hline$\Delta \mathrm{S}$ (days) & $7.1 \pm 2.5$ & $7.4 \pm 1.7$ & 0.66 \\
$\Delta \mathrm{H}$ (days) & $12 \pm 6$ & $11 \pm 5$ & 0.81 \\
$\Delta \mathrm{F}$ (days) & $3 \pm 4$ & $2 \pm 3$ & 0.64 \\
$\Delta \mathrm{P}_{\text {cr }}$ (days) & $10 \pm 6$ & $9 \pm 6$ & 0.83 \\
$\Delta \mathrm{TB}$ (days) & $8 \pm 3$ & $8 \pm 3$ & 0.70 \\
$\Delta$ Plat (days) & $5 \pm 2$ & $4 \pm 2$ & 0.61 \\
\hline
\end{tabular}

$\Delta \mathrm{S}$ - days between the onset of symptoms and hospital admission; $\Delta \mathrm{H}$ - days of hospitalization; $\Delta \mathrm{F}$ - days of fever; $\Delta \mathrm{P}_{\mathrm{cr}}$ - days to normalization of creatinine; $\Delta \mathrm{TB}$ - days to total bilirubins normalized or reached $1 / 3$ of maximum value; $\Delta$ Plat - days to normalization of platelets counts.

Table 5

Positive fluid balance, oliguria, and dialysis of treated and untreated groups

\begin{tabular}{lccc}
\hline & $\begin{array}{c}\text { Group T } \\
(\mathrm{n}=16)\end{array}$ & $\begin{array}{c}\text { Group nT } \\
(\mathrm{n}=19)\end{array}$ & $\mathrm{p}$ \\
\hline Positive Fluid Balance (\%) & 81 & 79 & 0.60 \\
Oliguria (\%) & 19 & 5 & 0.31 \\
Dialysis (\%) & 50 & 52 & 0.57 \\
Number of dialysis sessions & $2.0 \pm 3.0$ & $1.4 \pm 1.7$ & 0.52 \\
\hline
\end{tabular}

epidemic outbreaks may happen during heavy rain seasons, when flooding occurs. In the state of Ceará, the incidence of leptospirosis for the year 1995 was of 5.9 cases per 100,000 inhabitants, in a year with a high rainfall index. During the period from 1985 to 1996, 1,082 cases of leptospirosis were confirmed in Ceará, with a fatality rate of $4 \%$ (data furnished by SESA-Department of Epidemiology of the State of Ceará, August 1998). In the severe forms of leptospirosis associated with ARF, mortality rates are elevated, occasionally reaching around $22 \%$.

The specific antibiotic treatment of leptospirosis has been considered effective during the clinical course of disease only when implemented early on and in those cases where jaundice has not occurred. In the severe form of the disease, treatment has been shown to be of little effect, although there is a reduction in leptospiruria ${ }^{9}$. In contrast, WATT et al. ${ }^{25}$ in prospective double-blind, placebo controlled study of 42 patients, demonstrated beneficial effect of the treatment with intravenous penicillin, beginning on the ninth day after onset of disease, in 23 patients with severe leptospirosis (ARF and/or jaundice). In the treated group, the time after which leptospiruric and fever disappeared, the number of days of hospitalization and the time required for normalization of plasma creatinine were significantly lower than those of the placebo group ${ }^{25}$. In the present study the penicillin treatment began, on average, in seventh day after onset of symptoms and no difference was observed between the two groups regarding the time from onset of symptoms until admission, length of hospital stay, duration of fever and time until normalization of renal function.

Although leptospirosis in children is less frequent and has a better prognosis than adults there was no consensus about the influence of antibiotics on the evolution of Weil's disease in pediatric patients. MAROTTO et al. ${ }^{13}$, while analyzing retrospectively 43 children (ages variation 4 to14 years) with severe leptospirosis and ARF in $79 \%$ and jaundice in $70 \%$, observed that the 28 children treated with penicillin or ampicillin presented normalization of thrombocytopenia and plasma creatinine in shorter periods than when compared to the 15 children who did not receive the antibiotic. Therefore, those authors concluded that the use of antibiotic seems to curtail the duration of clinical manifestations of the disease and, consequently, the course of ARF. In the present study, with adult patients, no significant difference was observed between the treated and untreated groups in terms of time required for normalization of thrombocytopenia and normalization of plasma creatinine or regarding the duration of disease.

Unlike the above reports, EDWARDS et al. ${ }^{9}$, in prospective, randomized and controlled study of 79 patients with average age of 40 years and with the icteric form of leptospirosis, did not observe a difference in time required for normalization of biochemical parameters, duration of fever and mortality rate when comparing 38 penicillin treated patients with 41 untreated patients. Our group had already analyzed retrospectively 91 patients with leptospirosis and ARF with average age of 40 years, also observed that 32 patients treated with penicillin displayed duration of hospital stay, clinical manifestations, and mortality rates similar to those of the untreated group ${ }^{6}$. These studies are in keeping with the findings of the present study, in which no difference was observed between the two groups regarding parameters of clinical recovery, maximum and minimum laboratory exam values upon admission and survival rates.

In the present study was verified that penicillin treatment does not alter the course of the disease in patients with jaundice and ARF leptospirosis. The data in the literature remain controversial with regard to the late use of specific antibiotic therapy for severe leptospirosis. The majority of reports includes patients with both mild and severe leptospiral illness $s^{6,9,10-13,18,25}$. Some authors described the beneficial effects of doxycycline in early anicteric leptospirosis ${ }^{14}$. WATT et al. ${ }^{25}$ have suggested that in a placebo-controlled study, intravenous penicillin shortened the duration of fever and hospitalization and creatinine levels returned to normal faster in treated patients. However, only $76 \%$ of their 42 patients had either hepatic or renal dysfunction and no details were given of the distribution of the other $24 \%$ of patients among the penicillin and placebo groups. Their patients presenting on the ninth day of illness without renal or hepatic dysfunction cannot be considered to have severe leptospirosis and it is impossible to deduce the outcome if these patients were excluded from the analysis. EDWARDS et al. ${ }^{9}$, similar to our study, showed that antibiotic therapy with intravenous penicillin does not alter the course of the disease in patients with icteric leptospirosis.

The beneficial effects of penicillin on affected kidneys have particular clinical relevance. Serum creatinine rises lasted only a third as long in treatment group and leptospiruria diminished with penicillin. These findings suggest that it is by eradicating leptospires that penicillin shortens the duration of renal dysfunction ${ }^{25}$. It was seen in this study that number of days the patient presented with $\mathrm{P}_{\mathrm{cr}} \geq 1.5 \mathrm{mg} / \mathrm{dL}$ were similar in both groups indicating renal dysfunction. However, treated patients experienced greater proteinuria in the acute phase than those in the untreated group. These results could suggest that the use of penicillin may contribute to the intensification of proteinuria. Penicillin is described 
in the literature as a cause of acute interstitial nephritis and therefore could lead to a moderate proteinuria ${ }^{7,20}$.

An obstacle to specific antibiotic therapy in leptospirosis would be the possibility of induction of the Jarisch-Herxheimer reaction (JHR). Toxins released by lysis of the leptospires by antibiotic may induce cytokines. Treatment with penicillin releases limulus lysate active material in some patients, independent of and in the absence of a JHR. Several studies in which the effects of treatment were evaluated did not exhibit this complication ${ }^{13,14,25}$. In prospective controlled study to identify posttreatment JHR in 40 patients, in only one patient was observed JHR and he had received a placebo ${ }^{24}$. In the present study no cases of JHR were observed.

All patients in the present study received adequate clinical support and early indication of dialysis, when indication occurred. There was no difference in the indication of dialytic treatment nor in the number of sessions between groups $\mathrm{T}$ and $\mathrm{nT}$. The initial option always was early indication of intermittent peritoneal dialysis for both groups.

In contrast to the findings in the literature where the mortality rate of patients with the severe form of leptospirosis with jaundice and ARF was elevated from 20 to $50 \% \%^{5,21}$. We observed 4 patients, on penicillin therapy, who died within the first 48 hours of admission with massive hemoptysis and they were excluded from this study because this protocol was designed to evaluate renal function, at least, during the first week of hospitalization. Therefore, in this study only one patient died and he was on penicillin therapy. Thus, groups $\mathrm{T}$ and $\mathrm{nT}$ presented the same severity of clinical manifestations and the global mortality rate was low. Perhaps the early indication of dialysis and avoidance of hyperhydration, correction of hyperkalemia had influence towards a lower mortality rate.

The present study was not designed to evaluate the role of treatment on leptospiruria. Various authors have demonstrated that penicillin-based treatment reduces the period of leptospiruria ${ }^{9,25}$.

In conclusion, it was not shown that treatment with penicillin initiated at the end of the first week of disease would necessarily improve the clinical evolution of adult patients with leptospirosis and ARF. On the other hand, detrimental effects of the same also were not observed, with the exception of the increase in proteinuria in the acute phase of disease. Perhaps the hydration and the early dialytic treatment are more important than the specific antimicrobial therapy in such severe cases of leptospirosis and ARF.

\section{RESUMO}

\section{Avaliação do tratamento com penicilina em pacientes com leptospirose e insuficiência renal aguda}

A eficácia da antibioticoterapia no tratamento da leptospirose humana tem sido motivo de discussão. Como parte de um trabalho prospectivo para avaliar a recuperação da função renal após a insuficiência renal aguda (IRA) da leptospirose (IRA definida como $\mathrm{P}_{\text {cr }} \geq 1,5 \mathrm{mg} / \mathrm{dL}$ ), comparou-se a evolução clínica durante a internação de 16 pacientes, com leptospirose grave, tratados (T) com 18 não tratados (nT). O tratamento com ou sem penicilina foi opção de cada infectologista responsável pelo paciente. Quando tratados, foi administrado penicilina 6 milhões de U/dia por 8 dias. Os parâmetros analisados como idade, sexo, tempo do início dos sintomas à admissão, exames laboratoriais da admissão e internação não foram significativamente diferentes nos dois grupos, exceto pela proteinúria que foi significativamente mais elevada no grupo T. A recuperação clínica da doença avaliada pelo tempo: de internação, de febre, para função renal e níveis de plaquetas normalizarem e para os níveis de bilirrubinas totais caírem a $1 / 3$ do valor máximo ou normalizar não foram diferentes no grupo tratado e não tratado. A indicação do tratamento dialítico e a mortalidade também não foram diferentes nos dois grupos. Conclui-se que na leptospirose com IRA o tratamento com penicilina não mudou o curso da doença.

\section{ACKNOWLEDGMENTS}

We wish to thank Regina Célia R. M. Abdulkader, M.D., PhD, from Acute Renal Failure Group, Hospital das Clínicas of São Paulo, Nephrology Division, Faculty of Medicine, University of São Paulo for orientation to this study. We also thank our colleagues, residents and nurses from Walter Cantídio University Hospital, Faculty of Medicine, University of Ceará, São José Infection Disease Hospital and Nephrology Institute of Ceará for the assistance to patients. This work was supported in part by grant from CAPES.

\section{REFERENCES}

1. ALEXANDER, A.D. \& RULE, P.L. - Penicillins, cephalosporins and tetracyclines in treatment of hamsters with fatal leptospirosis. Antimicrob. Agents Chemother., 30: $835-839,1986$.

2. CAMARGO, E.D.; SILVA, M.V.; BATISTA, L.; VAZ, A.J. \& SAKATA, E.E. - Avaliação do teste ELISA-IgM no diagnóstico precoce da leptospirose humana. Rev. Inst. Med. trop. S. Paulo, 34: 355-357, 1992.

3. CHANG, S.L. - Studies on Leptospira icterohaemorrhagiae and in leptospirosis in guinea pig. J. clin. Invest., 25: 752-760, 1946.

4. CLEIN, L. - Penicillin in leptospirosis. Brit. med. J., 3: 354, 1973.

5. DAHER, E.F.; ZANETTA, D.M.T.; CAVALCANTE, M.B. \& ABDULKADER, R.C. Risk factors for death and changing patterns in leptospirosis acute renal failure. Amer. J. trop. Med. Hyg., 61: 630-634, 1999.

6. DAHER, E.F.; CAVAlCANTE, M.B.; BARROS, A.D.M. et al. - Penicillin therapy in leptospirosis acute renal failure (ARF): is there some benefit? In: ISN SATELLITE SYMPOSIUM OF ACUTE RENAL FAILURE, Cairns, Australia, 1997. Abstracts. p. 94.

7. DHARNIDHARKA, V.R.; ROSEN, S. \& SOMERS, M.J. - Acute interstitial nephritis presenting as presumed minimal change nephrotic syndrome. Pediat. Nephrol., 12: 576-578, 1998

8. EDWARDS, C.N.; NICHOLSON, G.D. \& EVERARD, C.O.R. - Thrombocytopenia in leptospirosis. Amer. J. trop. Med. Hyg., 31: 827-829, 1982.

9. EDWARDS, C.N.; NICHOLSON, G.D.; HASSELL, T.A.; EVERARD, C.O.R. \& CALLENDER, J. - Penicillin therapy in icteric leptospirosis. Amer. J. trop. Med. Hyg., 39: 388-390, 1988.

10. FAIRBURN, A.C. \& SEMPLE, S.J.G. - Chloramphenicol and penicillin in the treatment of leptospirosis among British troops in Malaya. Lancet, 1: 13-16, 1956.

11. HALL, H.E.; HIGHTOWER, J.A.; RIVERA, R.D. et al. - Evaluation of antibiotic therapy in human leptospirosis. Ann. intern. Med., 35: 981-998, 1951. 
12. LAWSON, J.H. - Penicillin in leptospirosis. (Letter). Brit. med. J., 4: 109, 1973.

13. MAROTTO, P.C.F.; MAROTTO, M.S.; SANTOS, D.L.; SOUZA, T.N.L \& SEGURO, A.C. - Outcome of leptospirosis in children. Amer. J. trop. Med. Hyg., 56: 307$310,1997$.

14. McCLAIN, J.B.; BALLOU, W.R.; HARRISON, S.M. \& STEINWEG, D.L. - Doxycycline therapy for leptospirosis. Ann. intern. Med., 100: 696-698, 1984.

15. MINISTÉRIO DA SAÚDE. FUNDAÇÃO NACIONAL DA SAÚDE. CENTRO NACIONAL DE EPIDEMIOLOGIA. COORDENAÇÃO DE CONTROLE DE ZOONOSES E ANIMAIS PEÇONHENTOS. PROGRAMA NACIONAL DE LEPTOSPIROSE - Manual de Leptospirose. 2. ed. rev. Brasília, FNS/CNE, 1995. p. 7-98.

16. MUNNICH, D. \& LAKATOS, M. - Treatment of human leptospira infections with semicillin (ampicillin) or with amoxil (amoxycillin). Chemotherapy, 22: 372-380, 1976.

17. MUNNICH, D. \& LAKATOS, M. - Treatment of leptospirosis with Semicillin. Ther. hung., 20: 152-155, 1972.

18. NICHOLS, H. - Penicillin in leptospirosis. Brit. med. J., 2: 301, 1973.
19. NICODEMO, A.C.; DUARTE, M.I.S.; ALVES, V.A.F. et al. - Lung lesions in human leptospirosis: microscopic, immunohistochemical, and ultrastructural features related to thrombocytopenia. Amer. J. trop. Med. Hyg., 56: 181-187, 1997.

20. OOI, B.S.; JAO, W.; FIRST, M.R.; MANCILLA, R. \& POLLAK, V.E. - Acute interstitial nephritis. A clinical and pathologic study based on renal biopsies. Amer. J. Med., 59: 614-628, 1975

21. SEGURO, A.C.; LOMAR, A.V. \& ROCHA, A.S. - Acute renal failure of leptospirosis nonoliguric and hypokalemic forms. Nephron, 55: 146-151, 1990.

22. TAKAFUJI, E.T.; KIRKPATRICK, J.W.; MILLER, R.N. et al. - An efficacy trial of doxycycline chemoprophylaxis against leptospirosis. New Engl. J. Med., 310: 497 500,1984 .

23. WATT, G. - Leptospirosis. Curr. Opin. infect. Dis., 5: 659-663, 1992.

24. WATT, G.; PADRE, L.P.; TUAZON, M.L. \& CALUBAQUIB, C. - Limulus lysate positivity and Herxheimer-like reactions in leptospirosis: a placebo-controlled study. J. infect. Dis., 162: 564-567, 1990.

25. WATT, G.; PADRE, L.P.; TUAZON, M.L. et al. - Placebo-controlled trial of intravenous penicillin for severe and late leptospirosis. Lancet, 1: 433-435, 1988.

Received: 21 March 2000

Accepted: 10 July 2000 